\title{
Ultrastructure of the cerebral ganglion of the acanthocephalan Corynosoma strumosum
}

\author{
M.M. Salnikova, A.I. Golubev, L.V. Malutina, Ya.I. Zabotin \\ Kazan (Volga Region) Federal University, Kremlevskaya str., 18, Kazan, 420008, Russia. E-mail: \\ m_salnikova@mail.ru
}

\begin{abstract}
A fine study of the cerebral ganglion of the acanthocephalan Corynosoma strumosum, at the stage of the late acanthella, from the paratenic (reservoir) host the White Sea cod, Gadus morhua, which differs from the sexually mature form only by the proboscis inverted into the sheath, is conducted. Ganglion of Acanthocephala is located in the posterior third of the sheath cavity of the proboscis between the fibers of the retractor muscles, being separated from them only by a thin layer of fibrillar matrix. Ganglion consists of a cortex and a neuropile. The cortex is formed by three types of neurons, which, according to their position in the ganglion, can be divided into the peripheral neurons located on the periphery; central ones - located around the neuropile, and the intermediate - concentrated between the first two cell types. Each cell type is characterized by a number of cytological features. The integrity of the ganglion is ensured both by numerous and different by the complexity invaginated contacts of the surface membranes of neurons with extracellular material and external fibrillar matrix, and due to a large number of somasomatic connections. Among the latter ones there are synaptic contacts. According to the structure and nature of the introduction into the soma and into the processes of neighboring neurons, the outgrowths of the partner cells can be single, finger-like curved or branched. The cytoskeleton of the cytoplasm of somatic outgrowth consists of microtubules and neurofibrils. In all cases, the membranes of neuronal outgrowths are postsynaptic. From the side of presynaptic membranes in the contact area the vesicles different in size and structure are present. It is likely that the unusual architectonics of the ganglion of Acanthocephala, the peculiarity of nuclear-cytoplasmic bonds in their neurons and the unique structure of the invaginated contacts are typical features of organization of their nervous system at the cellular level.

How to cite this article: Salnikova M.M., Golubev A.I., Malutina L.V., Zabotin Ya.I. 2017. Ultrastructure of the cerebral ganglion of the acanthocephalan Corynosoma strumosum // Invert. Zool. Vol.14. No.2. P.182-189. doi: 10.15298/invertzool.14.2.13
\end{abstract}

KEY WORDS: Acanthocephala, Corynosoma strumosum, cerebral ganglion, ultrastructure, neuron, synapse.

\section{Ультраструктура церебрального ганглия скребня Corynosoma strumosum}

М.М. Сальникова, А.И. Голубев, Л.В. Малютина, Я.И. Заботин

Казанский (Приволжский) Федеральный Институт, Кремлевская ул., 18, Казань, 420008, Poccuя. E-mail: m_salnikova@mail.ru 
РЕЗЮМЕ: Проведено исследование тонкой организации церебрального ганглия скребня Corynosoma strumosum, на стадии поздней акантеллы, из паратенического (резервуарного) хозяина беломорской трески Gadus morhua, которая отличается от половозрелой формы лишь ввернутым во влагалище хоботком. Ганглий скребней размещен в задней трети полости влагалища хоботка между волокнами мышцретракторов, будучи отделенным от него лишь тонким слоем фибриллярного матрикса. Ганглий состоит из кортекса и нейропиля. Кортекс образован тремя типами нервных клеток, которые по положению в ганглии можно разделить на обкладочные - расположенные на периферии; центральные - находящиеся вокруг нейропиля, и промежуточные - сконцентрированные между первыми двумя типами клеток. Каждый из этих типов клеток характеризуется рядом цитологических особенностей. Целостность ганглия обеспечивается как за счет многочисленных и разных по сложности строения инвагинированных контактов поверхностных мембран нейронов с экстрацеллюлярным материалом и внешним фибриллярным матриксом, так и за счет большого числа сома-соматических связей. Среди последних есть контакты и синаптической природы. По строению и характеру внедрения в сому и в отростки соседних нейронов, выросты клеток-партнеров могут быть одиночными, пальцеобразно изогнутыми или разветвленными. Цитоскелет цитоплазмы соматических выростов состоит из микротрубочек и нейрофибрилл. Мембраны выростов нейронов во всех случаях являются постсинаптическими. Со стороны пресинаптических мембран в области контакта присутствуют различные по величине и структуре везикулы. Вполне вероятно, что необычная архитектоника ганглия скребней, своеобразие ядерно-цитоплазматических связей в их нейронах и уникальное строение инвагинированных контактов является типовыми признаками организации их нервной системы на клеточном уровне.

Как цитировать эту статью: Salnikova M.M., Golubev A.I., Malutina L.V., Zabotin Ya.I. 2017. Ultrastructure of the cerebral ganglion of the acanthocephalan Corynosoma strumosum // Invert. Zool. Vol.14. No.2. P.182-189. doi: 10.15298/invertzool.14.2.13

КЛЮЧЕВЫЕСЛОВА: Acanthocephala, Corynosoma strumosum, церебральный ганглий, ультраструктура, нейрон, синапс.

\section{Introduction}

For solving the problems of evolutionary morphology and phylogeny, a significant role belongs to parasitic animals, free-living ancestors of which occupied key positions, and they found themselves in dead ends of the evolutionary process. Among such organisms there are representatives of the pseudocoelomate worms - Acanthocephala. The tissue and cellular organization of Acanthocephala is mostly unique. All above-mentioned entirely applies to their nervous system, which makes acanthocephalans the unique objects for the study of the evolution and plasticity of primitive brain models.
In this paper, the first description of the ultrastructure of the cerebral ganglion in Corynosoma strumosum (Rudolphi, 1802) is given, at the stage of the late acanthella, which differs from the sexually mature form only by the proboscis inserted into the sheath.

\section{Materials and methods}

Acanthellae of Corynosoma strumosum were removed from the capsule from the outer side of the intestine of the White Sea cod Gadus morhua, caught in the Chupa Bay of the White Sea. The presomas (sheath with proboscis) of worms were cut off and fixed in a $1 \%$ solution of 
glutaraldehyde (SERVA, Germany) on $0.1 \mathrm{M}$ phosphate buffer (pH 7.4) for one day. Postfixation was performed in a $\%$ solution of osmium tetroxide (Moscow Chemical Plant) on the same buffer for 2 hours. After dehydration in alcohols and acetone, the tissue pieces were encapsulated in a mixture of epoxy (Epon-812, MNA, DDSA) resins (SERVA, Germany). Ultrathin sections were obtained on a microtome of Reichert-Jung Ultracut-E 6524-01 and viewed in an electron microscope JEM-1200CX. The survey was carried out on AGFA ORTHOCHROMATIC film. To obtain microphotographs, negatives were scanned on an EPSON PERFECTION 4990 PHOTO scanner at a resolution of 600 dpi.

\section{Results and discussion}

The cerebral ganglion of Acanthocephala is located in the posterior third of the sheath cavity of the proboscis between the fibers of the retractor muscles. In Corynosoma it has the form of a spindle in length of 215-250 microns and a width of 90-123 microns. From the ganglion, 13 paired and unpaired nerves that innervate all the organs of the animal depart (Randall et al., 1994). During the activity of the retractor muscles, the cerebral ganglion is constantly subjected to severe deformation. In the males of acanthocephalans, in addition to the cerebral ganglion, there is another paired genital ganglion located at the posterior end of the body.

Ultrathin structure of the ganglion envelope. The cerebral ganglion of C. strumosum is separated from the cavity of the proboscis sheath only by a thin $(0,5-2 \mu \mathrm{m})$ layer of fibrillar matrix (Fig. 1A). It is possible to observe the transverse striation of these fibrils, which allows identifying their collagen nature. The supporting role of this ganglion sheath can hardly be significant. Most likely, it carries out a barrier function. The ganglionic "envelope" not only surrounds the surface of the ganglion and the nerve strands departing from it, but also forms interlayers between nerve cells and their processes inside the ganglion (Fig. 1C). Closer to the center of the ganglion, the intercellular inter- layers become more homogeneous and thinner (from 0.1 to $0.2 \mu \mathrm{m}$ ).

Ultrastructure of nerve cells. The cerebral ganglion of acanthocephalans consists only of neurons (Bogoyavlensky, Ivanova, 1978; Golubev, 1982; Budziakowski et al., 1984). Ganglion consists of a cortex and a neuropile. The somas of neurons are located in the cortex, and the inner zone is occupied by their processes.

Depending on the location in the cortex of Corynosoma strumosum, three types of neurons can be distinguished: peripheral - located on the periphery; central - located around the neuropile, and intermediate neurons, which are concentrated between the first two types of cells. Each of these cell types is characterized by a number of cytological features. Neurons having a similar ultrastructure are arranged symmetrically relatively to the longitudinal axis of the ganglion.

Peripheral neurons. This group of neurons is the most numerous and forms the external somatic layer of the ganglion. Along with single-nucleon neurons, one double-nucleon nerve cell has been found. At the poles of the ganglion, the neurons are arranged in two layers. Neurons located on the periphery have large dimensions and elongated shape. In the peripheral neurons a large rounded nucleus with uneven contours (Fig. 1B) and a dense granular nucleolus is prominent in the center. Close to the nuclear envelope is a layer of lamina (70-80 nm wide), nuclear pores are located in the nuclear envelope. Neuroplasm seems fine-grained due to the abundance of free ribosomes. The mitochondria are rather few in the neurons of this zone. Their diameter reaches from 0.3 to $1.4 \mu \mathrm{m}$. Mitochondria have a granular matrix, penetrated with a small number of lamellar cristae, which are often difficult to identify, which is very characteristic for mitochondria of parasitic worms.

In the perikaryon of neurons, there are dictyosomes of the Golgi complex, neurotubules and secretory granules of two types. The first category includes small membrane-bound vesicles with a diameter of 50 to $80 \mathrm{~nm}$, filled with electron-transparent material. The second type granules are large, $60-120 \mathrm{~nm}$ in diameter, 


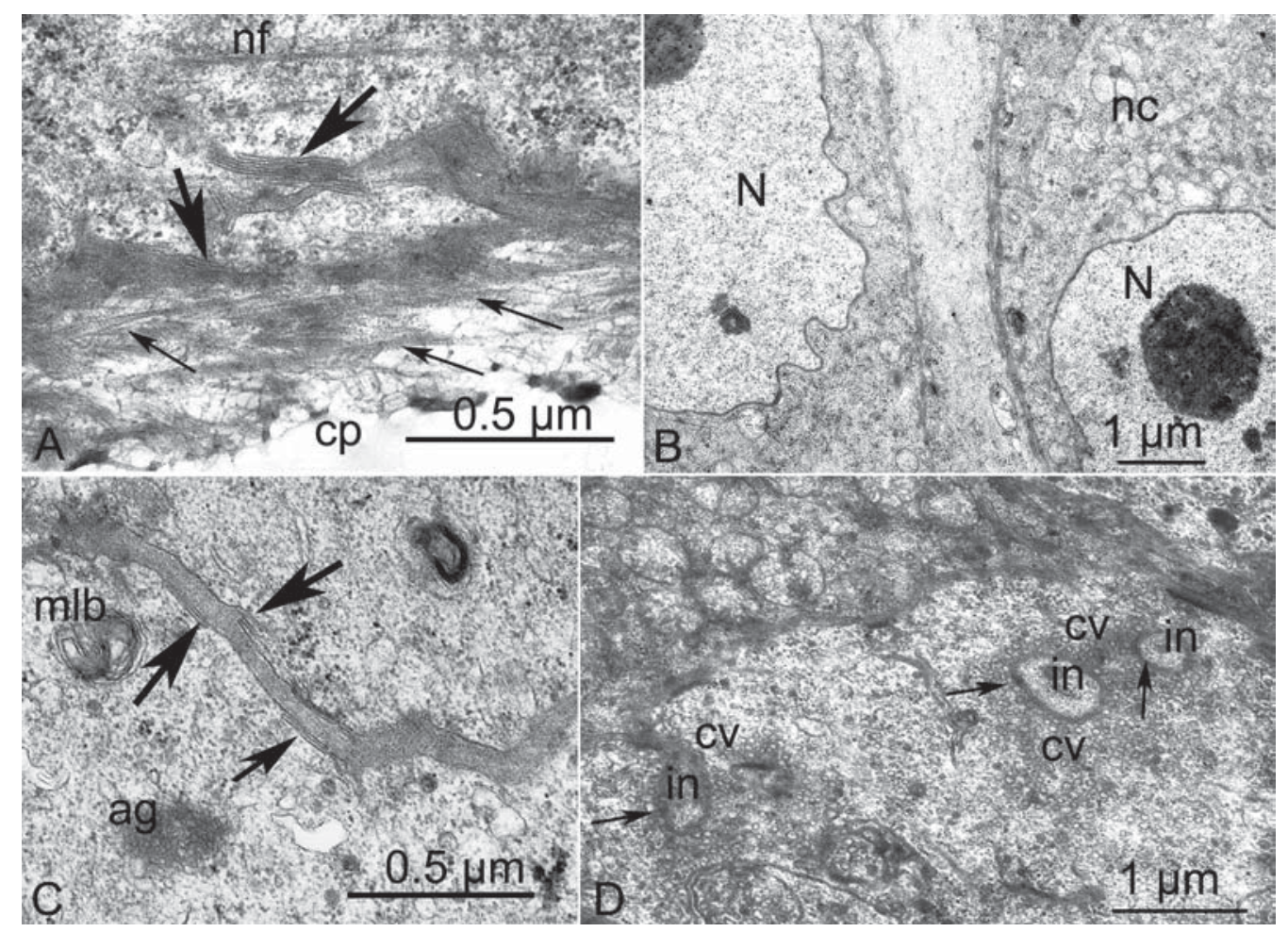

Fig. 1. Fragments of neurons of Corynosoma strumosum. A - envelope of the cerebral ganglion, thin arrows mark the collagen fibrils of the fibrillar matrix; B — fragments of peripheral neurons; $\mathrm{C}$ - homogeneous interlayers between neurons and specialized neurilemma contacts with intercellular matrix (thick arrows); D - neurons of the central zone, thin arrows mark synaptic contacts.

Abbreviations: ag — Golgi apparatus; $\mathrm{cp}$ - proboscis cavity; cv — synaptic vesicles; in — invagination of the neuron; $\mathrm{fm}$ - fibrillar matrix; mlb — multilamellar body; $\mathrm{n}$ - nucleus; $\mathrm{nc}$ - neuron; $\mathrm{nf}$ - neurofilaments.

Рис. 1. Участки нервных клеток Corynosoma strumosum. А - оболочка церебрального ганглия, тонкие стрелки показывают фибриллы коллагеновой природы фибриллярного матрикса; В участки нервных клеток периферической зоны ганглия; C - гомогенные прослойки между нейронами и специализированные контакты нейрилеммы с межклеточным веществом (толстые стрелки); Д - нейроны центральной зоны, тонкие стрелки показывают синаптические контакты.

Обозначения: ag — аппарат Гольджи; cp — полость хоботка; cv — синаптические везикулы; in — инвагинация нейрона; fm — фибриллярный матрикс; mlb — мультиламеллярное тело; n — ядро; nc — нейрон; nf — нейрофиламенты.

completely filled with a dense secret. Multilamellar bodies, lipid droplets $(0.5-1 \mu \mathrm{m})$ can be seen in any parts of the neurons (Fig. 1C).

Intermediate neurons. Intermediate neurons are usually located at the junction of neurons of the somatic layer and are easily recognized by a greater variety of structural components. They have a large nucleus, strongly cut by invaginations. Chromatin is finely granulated. A high electron density is typical for cell neuroplasm due to the accumulation of free ribosomes collected in rosettes. The perinuclear zone of neurons is literally packed with mitochondria and dictyosomes of the Golgi apparatus. Characteristically, the presence of large lipid droplets, transparent vacuoles, large enough and of different forms, secretory granules of two abovementioned types.

In these neurons more often than in other neuron types, the multilamellar bodies of differ- 

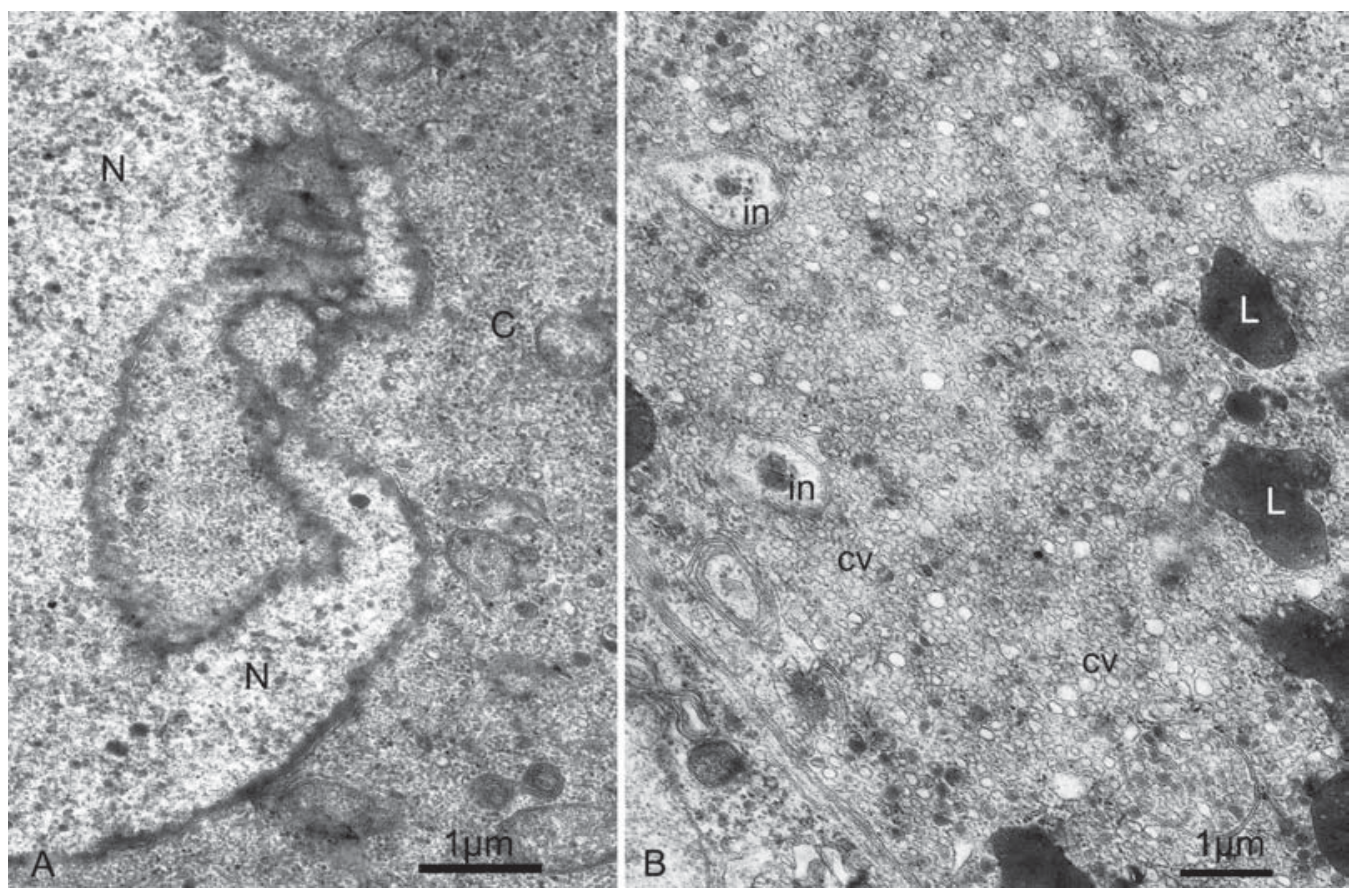

Fig. 2. Fragments of neurons of Corynosoma strumosum. A - intermediate neuron, invagination of nuclear envelope; B - fragment of the neurosecretory cell.

Abbreviations: $\mathrm{c}$ - cytoplasm; cv — synaptic vesicles; in — invagination of the neuron; 1 - lipid droplets, $\mathrm{n}$ - nucleus. Scale bar $1 \mu \mathrm{m}$.

Рис. 2. Участки нервных клеток Corynosoma strumosum. A 一 промежуточный нейрон, инвагинация ядерной оболочки; В - участок нейросекреторной клетки.

Обозначения: c — цитоплазма; cv — синаптические везикулы; in — инвагинация нейрона; 1 - липидные капли; $\mathrm{n}$ - ядро. Масштаб 1 мкм.

ent structure and size are found. Probably, the cells of this zone of the brain play a significant role in the trophism of the ganglion.

Neurons of the central zone. Neurons of the central zone have rounded, without invaginations of karyolemma, nuclei with finely granulated chromatin. In the neuroplasm, the clusters of secretory vesicles of various types, dictyosomes of the Golgi apparatus, free ribosomes, mitochondria, and small vacuoles are noted. Multilamellar bodies and lipid droplets are rare (Fig. 1D).

Among the neurons of the central zone three highly specialized cells are distinguished. One of them can be unmistakably called neurosecretory. In any area of its neuroplasma, secretory granules with a diameter of $80-120 \mathrm{~nm}$, with a material of high electron density, are abundant.
The body of the neurosecretory cell is strongly elongated along the length of the ganglion (Fig. 2B) and gives many processes towards the neighboring neurons. The cytoplasm of the other two neurons is filled with small vacuoles and electronically transparent bubbles of round and oval shape with sizes up to $60 \mathrm{~nm}$. For such an original structure they can be called "bubble" (Fig. 3C).

A common feature for all ganglion cells is the extremely poor development of the endoplasmic reticulum.

Neuropile. Neuropile is located in the center of the cerebral ganglion of C. strumosum. It is formed by the processes of all types of neurons identified in the ganglion. No envelopes surrounding the neuropile were found.

Contacts of neurons with extracellular matrix and outer fibrillar matrix. The sheath of 

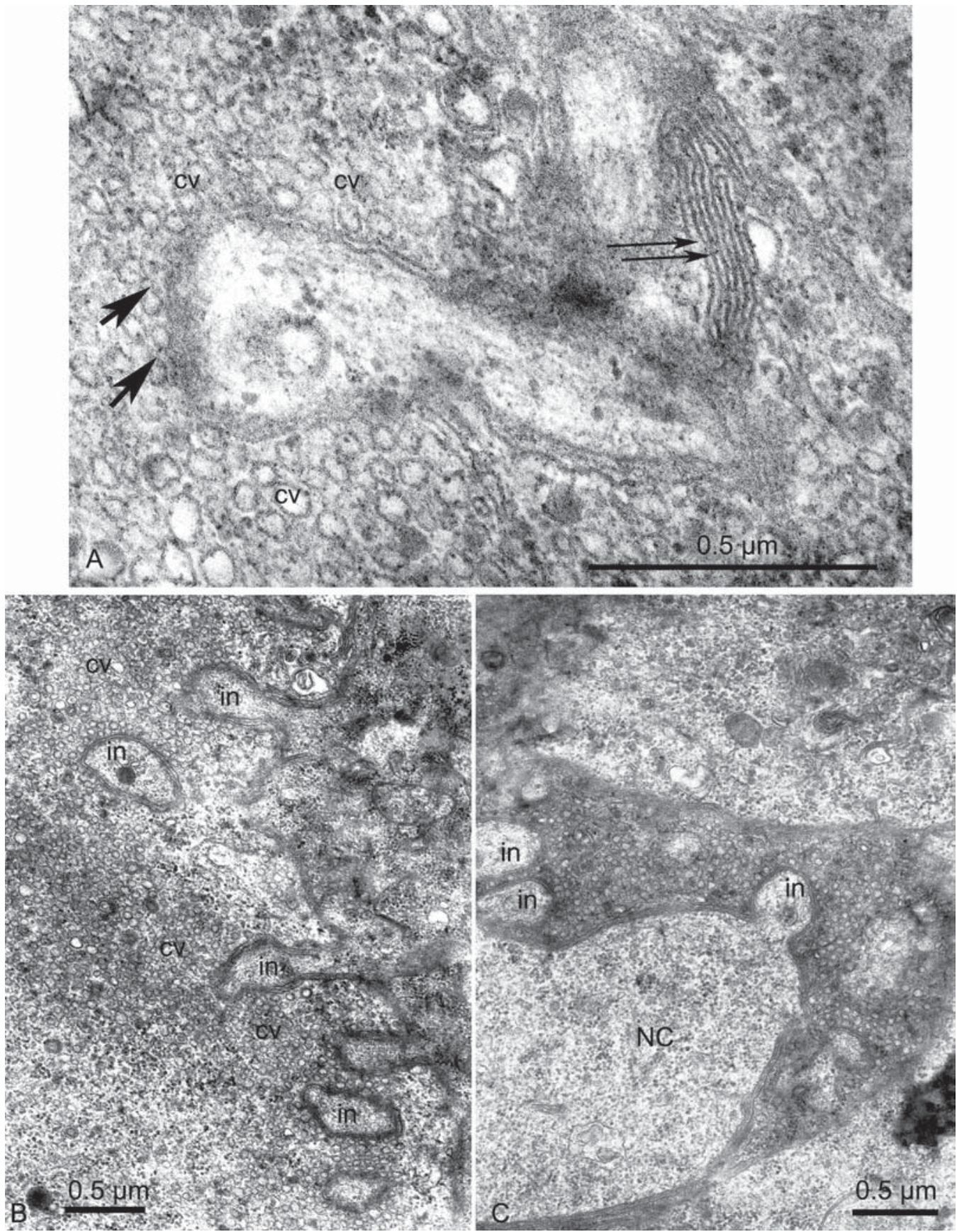

Fig. 3. Intercellular contacts in cerebral ganglion of Corynosoma strumosum. A - single soma-somatic synaptic contact (the synapse is marked with a thick arrow) and a complex supportive contact (marked with a thin arrow); B - multiple soma-somatic synaptic contacts; $\mathrm{C}$ - fragment of the bubble neuron, with multiple invaginations.

Abbreviations: $\mathrm{cv}$ — synaptic vesicles; in — invagination of the neuron. Scale bar $0.5 \mu \mathrm{m}$. 
the proboscis of the acanthocephalans is not the most tranquil place for the cerebral ganglion, since it is constantly subjected to severe deformations during the activity of the retractor muscles. How the morphological integrity of the ganglion is provided? Typical supportive compounds in the nervous system of invertebrates and vertebrate animals are connections such as desmosomes and "tight junctions" (Nemecek et al., 1978). Similar formations were not found in the cerebral ganglion of acanthocephalans.

To our opinion, the integrity of the ganglion is provided by the entanglement of the processes of the neurons in the central part of the ganglion, and also due to the multi-striated secretory cell passed through the entire ganglion and numerous simple and complex specialized contacts of the neurilemma with the extracellular matrix.

Simple contacts are represented by rather clearly identified sets of invaginations of the plasma membrane of neurons (Fig. 1A, C). Due to the combinations of different types of simple contacts, the cerebral ganglion receives a mass of complex connections, performing even more reliable coupling of neurons with the surrounding intercellular matrix. In any type of connections the invaginations inside the neuroplasm can change their direction, which makes the connection of cells with the intercellular substance even more reliable.

For the first time the contacts of neurons with extracellular matrix in acanthocephalans were revealed by electron microscopic studies of the cerebral and genital ganglia of Echinorhynchus gadi (Golubev, Salnikov, 1979; Golubev, Abdrakhimov, 1986). Other data on the finding of such contacts was not found in the literature. The Canadian scientists (Budziakowski et al., 1984) showed in the cerebral ganglion of the parasite Moniliformis moniliformis, parasitic in American rats, the neurilemma invagi- nations that form channels up to $40 \mathrm{~nm}$ in width, $1.3 \mu \mathrm{m}$ long, filled with extracellular substance. As the authors suggest, these channels could represent a system for the rapid penetration of substances into the neuronal perikaryon both in the radial and in longitudinal directions.

Intercellular contacts. In the cerebral ganglion of acanthocephalan Corynosoma strumosum, the somas of the neurons and their processes are often penetrated by the large processes of neighboring nerve cells, forming soma-somatic outgrowths. The functions of such soma-somatic contacts can be different: supporting, trophic or synaptic.

Neurotrophic contacts. Soma-somatic neurotrophic contacts look like the implantation of the processes of one neuron into the body of another. They are widely represented both in the somatic and in the intermediate zones of the ganglion.

Synaptic contacts are found not only in the ganglion neuropile, but also in the cortex (Fig. $3 \mathrm{~A}-\mathrm{C}$ ). Depending on the structure and nature of the implantation into the soma and outgrowths of neighboring neurons, the outgrowths of the partner cells can be single, finger-shaped or branched. It is difficult to estimate the length of outgrowths, they can strongly and bizarrely curve, penetrating into the neuroplasm of neighboring neurons (Fig. 3B). The length of outgrowths may depend on the plane of the cut through them. Deep penetration of more than $1.6 \mu \mathrm{m}$ was observed. The width (diameter) of them in the region of the neuropile varies from 0.3 to $0.8 \mu \mathrm{m}$, more often than others, inclusions with a width of about $0.5-0.6 \mu \mathrm{m}$ occur. The distance between the membranes of the contacting cells is about $120 \mathrm{~nm}$, and the intercellular material between them is lost. In all cases, the membranes of the outgrowths of the neuron are postsynaptic. From the side of presynaptic membranes in the area of contact there is a large

Рис. 3. Межклеточные контакты в церебральном ганглии скребня Corynosoma strumosum. A одиночный сома-соматический контакт синаптического характера (синапс отмечен толстой стрелкой) и сложный опорный контакт (отмечен тонкой стрелкой); В - множественные сома-соматические контакты синаптического характера; C - участок пузырчатого нейрона, с множественными инвагинациями.

Обозначения: cv - синаптические везикулы; in - инвагинация нейрона. Масштаб 0,5 мкм. 
number of vesicles different in size and structure. Small (30 $\mathrm{nm}$ in diameter) round electrontransparent vesicles appear closely to the presynaptic membrane or even contact with it. Slightly deeper the larger round (up to $55 \mathrm{~nm}$ in diameter) or oval ( $55 \mathrm{~nm}$ in length and $25 \mathrm{~nm}$ in width) light vesicles are located. Beside them the granules $80-120 \mathrm{~nm}$ in diameter, partially or completely filled with material of high electron density, scattered singly or in small groups. Preand postsynaptic membranes are parallel to each other. The first ones appear slightly thickened; the width of the synaptic cleft does not exceed $16-21 \mathrm{~nm}$ and contain an electron-dense material (Fig. 3A). Zones of active contacts can be found along the entire circumference of the somatic outgrowth.

For the first time, the presence of invaginated synaptic contacts in Acanthocephala was shown in studies of the cerebral and genital ganglia of Echinorhynchus gadi (Golubev, Abdrakhimov, 1986). Earlier (Budziakowski et al., 1985) the synaptic contacts were found between small neurites in the neuropile of the cerebral ganglion of the acanthocephalan Moniliformis moniliformis.

Histochemical methods and radioenzyme analysis (Budziakowski et al., 1983) revealed the biogenic amines in the neurons of acanthocephalan Moniliformis moniliformis: large amount of catecholamines and lesser adrenaline, noradrenaline, octopamine. Using the immunocytochemical method in 2007, the GABAergic neurons in the cerebral ganglion of the acanthocephalan Echinorhynchus gadi (Salnikova et al., 2007) were detected on ultrathin sections.

In the organization of cerebral ganglia of all studied species of Acanthocephala, one detail is very clearly defined: in the construction of supportive connections of neurons and intercellular matrix, the soma-somatic neurotrophic contacts and synaptic connections, the same single prin- ciple of deep invagination of the surface membrane is determined. It is likely that the unusual architectonics of the ganglion of acanthocephalans, the peculiarity of nuclear-cytoplasmic bonds in their neurons and the unique structure of the invaginated contacts are typical signs of the organization of their nervous system at the cellular level.

\section{References}

Bogoyavlenskii Yu.K., Ivanova G.V. 1978. [Microstructure of tissues of acanthocephalans]. Moscow: Nauka. 206 p. [in Russian]

Budziakowski M.E., Mettrick D.F. 1985. Ultrastructural morphology of the neuropile of the cerebral ganglion of Moniliformis moniliformis (Acanthocephala) // J. Parasitol. Vol.71. No.1. P.75-85.

Budziakowski M.E., Mettrick D.F., Webb R.A. 1983. Aminergic neurons in the anterior nervous system of the rat acanthocephalan Moniliformis dubius // J. Neurobiol. Vol.14. P.313-170.

Budziakowski M.E., Mettrick D.F., Webb R.A. 1984. Ultrastructural morphology of the nerve cells in the cerebral ganglion of acanthocephalan Moniliformis moniliformis // J. Parasitol. Vol.70. No.5. P.719-734.

Golubev A.I. 1982. [Electron microscopy of nervous system of worms]. Kazan: Izdatelstvo Kazanskogo universiteta. 108 p. [in Russian].

Golubev A.I., Abdrakhimov F.A. 1986. [Anatomy and ultrastructure of genital ganglion of acanthocephalan Echinorhynchus gadi]// Parazitologiya. Vol.20. No.4. P.294-299. [in Russian].

Golubev A.I., Salnikov V.V. 1979. [Ultrastructure of specific connections neuron - intercellular matrix in the cerebral ganglion of acanthocephalan] // Tsitologiya. Vol.21. No.9. P.1100-1102. [in Russian].

Nemecek S. 1978. [Introduction to neurobiology]. Praga: Med. Izdatelstvo. 416 p. [in Russian].

Randall J.G., Holloway J.R. 1994. Praesomal Nerves in Corynosoma hamanni (Acanthocephala: Polymorphidae) // J. Morphol. No.219. P.247-256.

Salnikova M.M., Golubev A.I., Biserova N.M. 2007. [Fine structure of cerebral ganglion of acanthocephalan Echinorhynchus gadi (Acanthocephala) and detection of GABA-ergic neurons there] // Materialy IV Vserossiiskoi shkoly po teoreticheskoi i morskoi parazitologii. May 21-26, 2007. Kaliningrad: AtlantNIRO. P.189-191 [in Russian].

Responsible editor E.N. Temereva 